\title{
Leisure Technology for the Elderly: A Survey, User Acceptance Testing and Conceptual Design
}

\author{
Chow Sook Theng \\ School of Computer Sciences \\ Universiti Sains Malaysia \\ 11800, Penang, Malaysia
}

\author{
Saravanan Sagadevan \\ School of Computer Sciences \\ Universiti Sains Malaysia \\ 11800, Penang, Malaysia
}

\author{
Nurul Hashimah Ahamed \\ Hassain Malim \\ School of Computer Sciences \\ Universiti Sains Malaysia \\ 11800, Penang, Malaysia
}

\begin{abstract}
The Alzheimer's disease damages neuronal and synaptic system due to the high level of amyloid beta in the brain. It is the common cause of dementia which is more common to afflict the elderly where they will gradually loss their memory and communication skills as well as deterioration of thinking and reasoning ability. Hence, it is crucial for elderly people to monitor their cognitive performance consistently and continuously to detect the Alzheimer's symptoms, such as dementia or Mild Cognitive Impairment. There are many technologies that have been established in healthcare for its detection; however, such technologies, mostly medical treatments could not be self-catered by elderly on daily basis and in fact the use of this technology incurs cost each time. Therefore, this study looks at an alternative technology called leisure technology that allows access to the elderly every day at home in an enjoyable and relaxing manner. The aim of this study is to study applications of leisure activities that could stimulate brain cognitive function to be turned to a leisure technology application. Prior to proposing the conceptual design of this application, a user acceptance study of leisure technology among elderly people has been conducted. This study involves interviews and survey through distribution of questionnaires. The survey results shows that $90 \%$ of the participants stated that there was an improvement in cognitive abilities after using leisure technology and $98.4 \%$ of the participants stated that they could adapt to leisure technology. On the other hand, the outcomes from the interview show that they agreed that different types of leisure technology provide heterogeneous benefits, which can improve their cognitive abilities. Finally, this study proposes a conceptual design for leisure technology application that elderly people can adapt to.
\end{abstract}

Keywords-Leisure technology; user acceptance; cognitive ability; elderly

\section{INTRODUCTION}

The development of sophisticated technologies has made our life easier. According to Merriam-Webster dictionary, technology is the application of knowledge in a specific area. Based on the definitions stated by Sixsmith and Gutman [1], technologies could help people in their daily tasks as they can perform independently. Although most of the application based technologies were developed regardless of age limitation, there are some programs created to particular focus groups such as children, males, disabled, school kids, and so on. We have observed that, application developers emphasize less on the needs of elderly people though there are several solid evidences showing that technology can allow them to enjoy meaningful activities. Furthermore, elderly people generally have some limitations and interests that differ from other focus groups. For instance, the characteristics of games that contain small objects and prompt the user to make rapid movement or changes that could cause discomfort in elderly people. Moreover, elderly people are often vulnerable to diseases; therefore the development of an application that focuses on reducing the threat or improving the quality of life of people with Alzheimer's and dementia is important. In order to fill the gap in research, this study analyzes the effectiveness of leisure technologies in reducing the risk of Alzheimer's and measures the acceptance level of leisure technology among elderly people. Then, we propose a conceptual design of elderly leisure technology game with the intention to reduce the risk to Alzheimer's among elderly people. The application was develop by integrating three types of leisure elements namely game, music and arts.

This paper discusses the concept, types and current trends of leisure technologies in Section II. It is then followed by the methodology of the user acceptance testing for leisure technology among the elderly and the preferred features in Section III; the findings in Section IV; the application design in Section V; and the conclusion in Section VI.

\section{LEISURE TECHNOLOGY AS A MEANS TO IMPROVE ELDERLY COGNITIVE ABILITY}

This section reviews Alzheimer's, leisure technology, games and other systems to improve elderly people's health, existing leisure technology and user acceptance of leisure technology among elderly people.

Alzheimer's disease is defined as damages in the neuronal and synaptic system in the brain, thus causing loss of memory [2]. If it gets worse, it will affect the behaviour and cognitive functions in cortical and sub-cortical regions of the brain. At that stage, the disease will impair motor abilities. Orrell and Sahakian [3] stated that mental stimulating activities can retain a person's intellectual level as it is important for their cognitive function and memory skills. Thus, it is important to reduce the symptoms of Alzheimer's in order to understand their health conditions, improve their social interaction with others, and be independent [4].

Leisure is the participation in activities that are enjoyable and relaxing during one's free time [5]. Lee and Groves [5] 
stated that leisure activities can develop new skills and broaden one's communication network. Leisure activity is defined as a hobby that is a part of a healthy lifestyle [6]. When elderly people involve themselves in cognitive leisure activities such as reading, playing puzzle, games, playing musical instruments, playing cards, listening to radio, the risk of suffering from dementia can be reduced and at the same time stimulating their brain neurons [7]. Thus, it is important for elderly people, especially those who had retired, to be involved in these types of activities [6]. On the other hand, as the definition of technology varies to each domain, from the perspective of elderly healthcare, Voice [8] labelled technology as an application that provides reminders and safety related issues for elderly people. In healthcare, technology plays an important role in delivering healthcare services to people within people's budget [1]. Although there are conservative perspectives saying that elderly people are less adaptive to current technologies, Lee and Groves [5] stressed that technology instruments such as computers, tablets or any other electronic devices are easily adapted by people in their daily lives. Furthermore, it is essential to people to know how to use technology in a correct way to obtain the most benefits from it [5].

Leisure technology can be defined either as computer systems or games that are developed by integrating leisure aspects. Riley, Alm, and Newell [9] stated that the development of a leisure system for elderly people with dementia could enhance their daily lives and allow them to participate in their favourite activities. Sixsmith and Gutman [1] stated that games are a part of technology that should be developed for elderly people to allow them to experience enjoyable moments in their life. Thus, by understanding the different descriptions of the terms leisure, technology, and leisure activities, we can integrate these terms and come up with a new description of leisure technology. Thus, leisure technology can encourage elderly people to enjoy and play their favourite games or applications or systems that help reduce the risk of getting Alzheimer's.

\section{A. Games}

Games is defined as activities of playing that people do to enjoy themselves or that function as an educational tool (Merriam-Webster). This section discuses three types of games namely action games, dancing games and puzzle games. These types of games are commonly associated with elderly people.

1) Action Games: In a broader term, action games are occasionally categorized within the video game genre that stresses on motor skills such as hand-eye coordination and rapid movements. Generally, action games' timing and levels emphasize on complexity of playing the games. Although action games that centred on rapid actions hinder many elderly people from playing such games, there was a study that investigated how action game types could help Dementia patients improve their health conditions. A study by Tobiasson [10] investigated on how Nintendo Wii Sports can help elderly people that suffered from Dementia to stimulate their body movements in order to improve cognitive thinking processes. The application extensively used motion sensor technologies as the interactions among users, actors and objects in the games and used game scores to measure the ability of the users to complete the games successfully. Tobiasson's [10] study made observations on the effects that occurred on elderly people when playing Nintendo Wii Sports games. The study found that the participants were more physically active and happier. The active physical movements and cheerful dispositions are essentials elements that could reduce the risks of getting Alzheimer's. However, the rapid movement requirement has become one of the drawbacks of the game that hinder elderly people from playing the Nintendo Wii Sports games.

2) Dancing Game: Dancing games are games that are played by moving hands, feet, or both as movements resembling a dance. A study by Arntzen [11] proposed a prototype of dancing game application based on Microsoft Xbox console that is connected to Kinect for input and a TV monitor for output. The prototype application applies infrared technology and Smart technology elements such as gesture recognition, facial recognition and voice recognition that can detect movements and voices of players. The dancing game starts with graphical information as guidance for users. Then, the dancing game starts slowly and gradually speeds up. The movements become more complex as the players become more skilled. The proposer claimed that the application were able to encourage and enhance the cognitive process and physical abilities of elderly people based on their survey and literature reviews.

3) Puzzle Game: Puzzle games are games that apply puzzle solving as the primary attraction to encourage people to play. Alzheimer's disease could be reduced by solving puzzles based challenges because such challenges require thinking processes and are occasionally used as a tool for psychomotor activity therapies to aid spatial orientation and vision [12]. This means that puzzle games can increase mental stimulation that activates the brain nerves or keep them active by improving their memory skills due to the processes that support the growth of new nerves cells in brain. Thus, elderly people that suffer from Alzheimer's can communicate well and actively engage with social activities [12]. Furthermore, puzzle games that use words/sentences as puzzle options could assist people with Alzheimer's to improve their language skills. One of the challenges that patients face is the inability to pronounce words well. By playing these games they are able to pronounce and understand words and sentences better [13]. There are several popular puzzle games such as Sudoku and Crossword. Thompson et al. [13] examined the effect of different types of puzzle games such as Sudoku, word puzzle and picture matching games on the health of people. The investigation found that Sudoku improved vision-spatial skills, word puzzle enhanced the level of IQ and reading ability, and picture-matching game improved the ability of visual memory. Besides that, another research study also claimed that the playing of crossword puzzle could slow down memory deterioration process of elderly people who suffer from 
Dementia due to an increased in Verbal Intelligence Quotient (VIQ) [14]. VIQ is a measurement of speaking abilities, verbal skills, ability to express themselves using appropriate vocabulary and ability to communicate with other people [14]. Kim et al. [15] proposed a name-face matching application named CogStim Game based on Cognitive Stimulation (CS) approach. There are two playing modes namely training and testing in the proposed application. In training mode, players are trained to match a particular name and face showed on the screen. In testing mode, there are several faces and names on the screen and participants need to match them. The game levels increase as the player becomes more skillful at the identification of names and faces. This game showed improvement in terms of visual ability by remembering people faces or names due to cognitive stimulation and improvement in memory abilities. Thus, these types of puzzle games that encourage thinking processes may help reduce the risk of getting Alzheimer's among elderly people.

\section{B. Other Systems to Improve Elderly People Health}

Although there are so many systems that could be used to improve the health of elderly people, this study focuses only on arts and musical systems.

1) Art System: Carrillo et al. [16] referred to art systems as creative approaches applied by people especially the elderly to pass time as well as therapy. There are several benefits of applying art systems to elderly people. One of the benefits is to keep elderly people active by making them engage creatively using the elements of arts. Moreover, the system can also increase social interaction which could possibly protect from Dementia and reduce aggressive behaviour. With the aid of computer programs, art based systems such as drawing can motivate elderly people with no art experience to engage themselves in an art system. Computer applications are able to provide wide range of user interfaces and functions for elderly people to freely draw [16]. For example, they could be provided with art templates for colouring, or dragging extra images to decorate a picture. The exposure to a variety of colours by drawing and thinking creatively can stimulate brain cells. As far as our literature review, there is no art system that is proven to reduce the risk of Alzheimer's disease. However, the literature review revealed that art therapies are practiced among elderly people to communicate using emotional and creative centres of the brain. According to Cowl and Gaugler [17], art therapy is a mental health therapy that uses the creative process of art making to improve the physical, mental and behaviours of elderly people. Elderly people can also overcome stress and emotional problems independently through creative processes.

2) Musical Application: Music has been well-known to provide relaxation to the brain. Moreover, it can also be used as a neuropsychological test for normal elderly people through the composition of music. Carrillo et al [16] stated that music can stimulate brain nerves on unresponsive patients in later stage of Alzheimer's disease. Riley et al. [9] proposed a music based application for people with Dementia to determine the ability of music in improving their creativity, communication skills and emotions. The prototype functions by letting participants listen to music and allowing them to use the system to create music. The applications do not require any musical skills or experiences and thus it is user friendly [9]. The outcome of this study showed that music indeed improved creativity, language skills and the ability to control the emotions of both healthy and elderly people with Dementia. Moreover, they were able to share their feelings with other people and communicate with each other properly. Besides that, there is also a music device called Remind created by a group of students in Sweden to help elderly people who suffer from Alzheimer's disease listen to music based on their playlist in order to remember part of their live [18]. The main purpose of this device was to trigger their memories and indirectly improve their memory skills. The music application was installed on a handset that could be controlled by family members or caregivers, and there was another wireless device provided for the patient to listen to the music. Although the students did not found any evidence to prove that the application provided positive impacts, they receive positive feedback from elderly people who recalled their memories [18].

\section{Hybrid-Based Leisure Technologies}

Presently, there is a product developed based on a combination of music and puzzle called Musical Bingo. The product has been designed for elderly people to recover memory losses and improve cognitive abilities based on customer's feedbacks [19]. However, this product has not been scientifically proven that it can reduce the risk of Alzheimer's disease. Apart from that, a system named Singing Fingers contains a combination of music and arts in touch screen electronic devices. Singing Fingers system has been designed to allow people to express their feelings and emotions through drawing and sounds. People can draw anything they want while the application records the music or what the person is saying. At the end, they could rewind the music by touching the drawing on the screen. The study by Rosenbaum and Silver [20] investigated the effects of Singing Fingers system on children. However, as far as we know, none of the study found investigated the effects of Singing Fingers system on elderly people.

The Virtual Supermarket is a computer application that virtualized the real supermarket and participants can shop in a manner comparable to a real supermarket. Zygourisa et al. [21] created a VSM application for elderly people to reduce Mild Cognitive Impairment (MCI) effectively. MCI is a symptom that is found at the early stage of Alzheimer's disease. The purpose of developing VSM is to screen, detect, prevent, and treat Mild Cognitive Impairment (MCI) among elderly people. The design of this application mimics the supermarket environments and players perform daily shopping in a supermarket when playing this game. The players are given a shopping list and they need to purchase the items on the shopping list. The players move around inside the supermarket to pick and purchase items, just like in reality. In addition, they 
need to select the amount of money to pay upon check out. At the end of the game, there is a statistics board appearing on the screen to show the results. The statistics shows the correct amount of money paid and the correct amount of items chosen from the shopping lists. Based on feedbacks from the users of VSM, elderly people were satisfied with VSM application in reducing the risk of early stage Alzheimer's disease. Thus, this game application will be a more relaxing and motivating way for elderly people to monitor their cognitive development and reducing costs in health care diagnosis. Once they realize that their cognitive development is deteriorating through VSM, they could undergo further diagnosis from clinics or hospitals.

\section{Special Features Consideration for the Elderly}

1) User Interface: Humans communicate with devices using mouse, keyboard and touch screen applications [22]. Nowadays, touch screen features widely on tablets, phones, laptops, and ATM machines. Thus, this feature has gained popularity among people of all ages. Elderly people that use touch screen tablets face several challenges such as difficulties in searching information and unable to type properly due to the lack of contact with a physical keyboard [23]. However, these drawbacks can be overcome by long use of tablets. Touch screen feature allows elderly people to select items on the screen straight away by using their fingers because it requires lesser visual spatial coordination. However, leisure technology should provide options for elderly people to choose whether they want to use keyboard or touch screens. It is also worth noting that Dhillon et al. [24] stated that elderly people prefer a game interface with more visual graphics such as buttons or images, than words.

2) Social Networking: According to Lee and Groves [5], elderly people are motivated to connect with other people through social network by sharing information such as pictures, videos and more. Thus, if these features are included in leisure application, this can motivate them to use leisure technology. Social network services can make their life meaningful and functional. The proposed leisure technology conceptual design allows elderly people to socialize by score ranking among friends and send game boosters to friends.

3) Reward Program: Koster [25] stated that people will not automatically play games unless they are attractive or coincidental that their hobby is playing games. Thus, if a game based application is included in a rewarding program, it can indirectly encourage them to feel excited about playing games [26]. There are several types of reward systems such as point accumulation and that could be used to redeem vouchers from participating outlets. A study done by Munson and Consolvo [27] proposed a mobile application that monitors the heart rate during exercise to motivate users by providing them rewards which are virtual trophies and ribbons with different ranking. Participants receive these rewards when they have achieved their goals of cardio exercises completion within four weeks. By motivating them through the referral reward program in leisure technology application, this will allow them to spread the benefits to other elderly people and encourage the usage of the application to reduce the risk of Alzheimer's disease.

4) Reminder System: Reminder system is an important feature for elderly people. According to Huppert [28] elderly people tend to forget things easily compared to younger people. Moreover, elderly people are dependent on reminder system such as calendar alerts because they are aware that they tend to forget things easily [28]. In the healthcare system, medical reminder is an important feature for elderly people such as to remind them to take medication at the proper time [29]. A study by Paggetti and Tamburini [30] on home care services stated that reminder system should be installed in mobile phones in order to remind elderly people to take medication.

\section{E. Summary of Leisure Technology}

The primary benefits of leisure technology are the ability to improve and maintain the functions of cognition in order to reduce the risk of Alzheimer's disease and encourage elderly people to accept the usage of leisure technology by providing user-friendly interfaces, reward program, reminder system and social networking platform. The literature review section has been about Alzheimer's disease, types of leisure technologies such as music, art and puzzle, various types of games, and so on. For the game section, compared to action and dancing games, we have determined that puzzle game is the most suitable game for elderly people because it requires less physical movements. In addition, this section has also discussed user acceptance of leisure technology among elderly people by determining the criteria of user interface and introducing a reward program, reminder system and social networking features to encourage them to use the application. Currently, no other studies have been found to combine music, puzzle, and art in a single application to improve the mental processes of elderly people and indirectly reduce the risk of Alzheimer's. Hence, this study embraces three types of leisure technologies namely art, music and puzzle that were previously studies by researchers to reduce Alzheimer's disease. The benefits of the three leisure technologies are described in Table I.

The next section discusses the methodology of this study to determine user acceptance of leisure technology among elderly people and development of a leisure application based on the feedbacks obtained from elderly people.

TABLE I. BENEFITS OF LEISURE TECHNOLOGIES

\begin{tabular}{|l|l|}
\hline $\begin{array}{l}\text { Types of Leisure } \\
\text { Technology }\end{array}$ & Benefits for Elderly People \\
\hline \multirow{2}{*}{ Art } & $\begin{array}{l}\text { •Able to stay active by thinking creatively on what to } \\
\text { draw. } \\
\text { •Increase the level of social interaction. } \\
\text { •Reduce aggressive behavior. }\end{array}$ \\
\hline Music & $\begin{array}{l}\text {-Trigger their memories and improve memory skills. } \\
\text {-Improve creativity, language skills and able to } \\
\text { control their emotions. } \\
\text {-Able to share their feelings with other people and } \\
\text { communicate with each other properly. }\end{array}$ \\
\hline Puzzle & $\begin{array}{l}\text {-Improves visuospatial skill. } \\
\text {-Improves the level of IQ and reading ability } \\
\text { •Improves visual memory. }\end{array}$ \\
\hline
\end{tabular}




\section{METHODOLOGY}

This study was conducted in two phases where the first phase was a user acceptance study to determine the acceptance level of the elderly of leisure technology and the second phase is the conceptual design of the leisure technology (see Fig. 1).

\section{A. Study on the User Acceptance of Leisure Technology among Elderly People}

This study employed questionnaire and interview methods to measure the user acceptance of leisure technology among elderly people. As mentioned in earlier, there were two types of user acceptance measurement namely subjective and instruments. This investigation used both types in order to further understand the desire of elderly people.

Subjective measurements included the user expectations on elements presented in the technology that will motivate them to adopt the technology, whereas instruments measurements involved models such as the Technology Acceptance Model (TAM) and Unified Theory of Acceptance and Use of Technology (UTAUT) model.

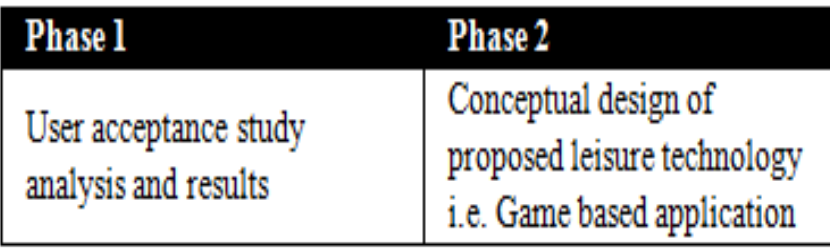

Fig. 1. Overall methodology.
According to Venkatesh et al. [31] there are several models and theories that combined to form Unified Theory of Acceptance and Use of Technology (UTAUT) such as Technology Acceptance Model (TAM), Diffusion of Innovation Theory (DoI), Theory of Reasoned Action (TRA), Theory of Planned Behavior (TPB), motivational model, combination of TAM and TPB models, PC utilization and social cognitive theory.

According to $\mathrm{Wu}$, Tao, and Yang [32] in terms of finding correlation between user behaviour and acceptance of technology, UTAUT is a better model that can determine more than $70 \%$ accuracy compared to other models and theories. The criteria or features that should be considered to determine the user acceptance of leisure technology among elderly people are user interface, social networking, reward program and reminder system.

1) Questionnaire development and distribution: This study used 8 determinants of UTAUT namely performance expectancy, effort expectancy, social influence, facilitating conditions, age, gender, experience, and voluntarity of use and three subjective features namely user interface, social networking and reward program to determine the user acceptance and the behaviour of elderly people towards leisure technology [31]. A total of 28 questions associated with 8 determinants from UTAUT Model (as shown in Table II) and 3 more questions based on subjective attributes (as shown in Table III) were distributed to respondents. The Google Form service was use as a tool to gather feedbacks from relevant respondents.

TABLE II. A SUMmary of 8 DETERMINANTS BASED ON UTAUT MODEL

\begin{tabular}{|l|l|l|l|}
\hline Determinants & Benefits for Elderly People & Functions (Questionnaires) & $\begin{array}{l}\text { Question Numbers in } \\
\text { the Questionnaires }\end{array}$ \\
\hline Age & $\begin{array}{l}\text { Determines which generation (young or old) is } \\
\text { exposed more to technology [31]. }\end{array}$ & $\begin{array}{l}\text { Determines how well elderly people accept that } \\
\text { leisure technology can reduce the risk of Alzheimer's } \\
\text { disease. }\end{array}$ & 1 \\
\hline Gender & $\begin{array}{l}\text { Determines the type of gender that is exposed } \\
\text { more to technology [31]. }\end{array}$ & $\begin{array}{l}\text { Determines the gender that accepts that leisure } \\
\text { technology can reduce the risk of Alzheimer's } \\
\text { disease. }\end{array}$ & 2 \\
\hline Experience & $\begin{array}{l}\text { Combination of a user's game experience and } \\
\text { knowledge [31]. }\end{array}$ & $\begin{array}{l}\text { Combination of an elderly person's experience and } \\
\text { knowledge in the usage of leisure technology. }\end{array}$ & $\begin{array}{l}3,4,5,6,7,8,9,11, \\
17,18\end{array}$ \\
\hline $\begin{array}{l}\text { Voluntaries of } \\
\text { use }\end{array}$ & $\begin{array}{l}\text { Determines who is willing to be exposed to the } \\
\text { usage of technology [33]. }\end{array}$ & $\begin{array}{l}\text { Elderly people are using leisure technology } \\
\text { voluntarily. }\end{array}$ & $20,21,22,23,25$ \\
\hline $\begin{array}{l}\text { Performance } \\
\text { expectancy }\end{array}$ & $\begin{array}{l}\text { A person believes that the system is beneficial } \\
\text { for that person's job performance [31]. }\end{array}$ & $\begin{array}{l}\text { Leisure technology provides different benefits for } \\
\text { elderly people. }\end{array}$ & $13,14,15,19,27$ \\
\hline $\begin{array}{l}\text { Effort } \\
\text { expectancy }\end{array}$ & $\begin{array}{l}\text { The user expects that the system must be easy to } \\
\text { use. Although the system can help user, if it is } \\
\text { difficult to use, the user will not use it [31]. }\end{array}$ & $\begin{array}{l}\text { Leisure technology should be user friendly and able } \\
\text { to encourage elderly people to use. }\end{array}$ & 12,24 \\
\hline Social influence & $\begin{array}{l}\text { A degree to which a user can be influenced by } \\
\text { others to use the new system [31]. }\end{array}$ & $\begin{array}{l}\text { A degree to which an elderly person can be } \\
\text { influenced by others to use leisure technology. }\end{array}$ & 23,26 \\
\hline $\begin{array}{l}\text { Facilitating } \\
\text { conditions }\end{array}$ & $\begin{array}{l}\text { A user believes that the usage of the system is } \\
\text { being supported by IT facilities [31]. }\end{array}$ & $\begin{array}{l}\text { A user believes that the usage of the system is being } \\
\text { supported by IT facilities. }\end{array}$ & 10,16 \\
\hline
\end{tabular}

TABLE III. A SUMMARY OF 8 DETERMINANTS BASED ON UTAUT MODEL

\begin{tabular}{|l|l|l|}
\hline Features & Survey questions & Purposes \\
\hline User interface & Leisure technology must be user friendly / simple. & $\begin{array}{l}\text { To understand the design of user interface that can motivate elderly } \\
\text { people to be involved in the usage of leisure technology. }\end{array}$ \\
\hline Social networking & Has information sharing feature (such as Facebook) & $\begin{array}{l}\text { To understand the preferred social interaction channel among elderly } \\
\text { people. }\end{array}$ \\
\hline Reward program & Reward Program (Collect points to redeem vouchers) & $\begin{array}{l}\text { To understand how important reward program is in attracting elderly } \\
\text { people to use leisure technology. }\end{array}$ \\
\hline
\end{tabular}


TABLE IV. The Benefits OF LEISURE TeChNOLOGIES

\begin{tabular}{|c|c|c|}
\hline No. & Questions & Purposes \\
\hline 1. & $\begin{array}{l}\text { After playing the art application, is there any improvement in your } \\
\text { memory skills? If yes, can you explain in detail? }\end{array}$ & $\begin{array}{l}\text { To determine the benefit of playing art application in terms of } \\
\text { cognitive abilities. }\end{array}$ \\
\hline 2. & $\begin{array}{l}\text { After using the music application, is there any improvement in your } \\
\text { memory skills? If yes, can you explain in detail? }\end{array}$ & $\begin{array}{l}\text { To determine the benefit of using music application in terms of } \\
\text { cognitive abilities. }\end{array}$ \\
\hline 3. & $\begin{array}{l}\text { After playing the puzzle application, is there any improvement in your } \\
\text { memory skills? If yes, can you explain in detail? }\end{array}$ & $\begin{array}{l}\text { To determine the benefit of playing puzzle application in terms of } \\
\text { cognitive abilities. }\end{array}$ \\
\hline 4. & $\begin{array}{l}\text { Did you experience any common physical or mental difficulty after } \\
\text { playing any of these games? If yes, what is that? }\end{array}$ & $\begin{array}{l}\text { To determine any side effect on their health after playing art, music } \\
\text { and puzzle applications. }\end{array}$ \\
\hline 5. & $\begin{array}{l}\text { Based on these three categories that you played, do they provide the same } \\
\text { benefits or different benefits in terms of improving your memory? }\end{array}$ & $\begin{array}{l}\text { To compare the benefits obtained from different types of leisure } \\
\text { technology - art, music and puzzle. }\end{array}$ \\
\hline 6. & $\begin{array}{l}\text { Based on these three categories you played, which category (art, music } \\
\text { and puzzle) do you prefer the most? Why? }\end{array}$ & To understand the preferred category chosen by participant. \\
\hline 7. & $\begin{array}{l}\text { After playing music }+ \text { art application, do you feel any different compared } \\
\text { to playing just one application? }\end{array}$ & $\begin{array}{l}\text { To determine the benefit of playing music }+ \text { art application in terms } \\
\text { of cognitive abilities. }\end{array}$ \\
\hline 8. & $\begin{array}{l}\text { Did you experience any common physical or mental difficulty after } \\
\text { playing music + art application? If yes, what is that? }\end{array}$ & $\begin{array}{l}\text { To determine any side effect on their health after playing the } \\
\text { combination of leisure technology, which are music and art } \\
\text { applications. }\end{array}$ \\
\hline 9. & $\begin{array}{l}\text { If you are the one proposing a conceptual design, which categories (art, } \\
\text { music and puzzle) do you want to include? Why? }\end{array}$ & $\begin{array}{l}\text { To understand the preferred category chosen by participant to be } \\
\text { included in the proposed conceptual design. }\end{array}$ \\
\hline 10. & $\begin{array}{l}\text { If you score badly in the game, do you want a system that can remind you } \\
\text { for a medical check up? If yes, why? If no, why? }\end{array}$ & $\begin{array}{l}\text { To determine how important reminder system is among elderly } \\
\text { people in healthcare system. }\end{array}$ \\
\hline 11. & $\begin{array}{l}\text { Do you want a game that can store a history of scores in order ao that you } \\
\text { can trace and understand on your cognitive performance better? If yes, } \\
\text { why? If no, why? }\end{array}$ & $\begin{array}{l}\text { To understand how important game history among elderly people is, } \\
\text { which can improve their cognitive performance. }\end{array}$ \\
\hline 12. & Do you have any suggestion for this study? & $\begin{array}{l}\text { To understand the feedback given by participants that is beneficial } \\
\text { for this study. }\end{array}$ \\
\hline
\end{tabular}

The questionnaire contained three sections. Section 1 was created to gather demographical information \& participant experience in the usage of leisure technology. Section 2 consisted of questions about user acceptance of leisure technology and Section 3 consisted of questions that require additional feedbacks from participants. As a pilot study, this investigation was conducted on a small group $(\mathrm{n}=60)$ at within the age range of 50 to 70 years old. A pilot study is a small-scale study that uses a small sample that can represent the total population of a study [34]. A pilot study can reduce errors and is less time consuming. This study was conducted by distributing questionnaires to eligible participants. The terms and conditions for this questionnaire were: 1) participants were between the age of 50 to 70 years old; 2) participants has had previous or current experiences in leisure technology using electronic devices such as a desktop computer, laptop, mobile phone or tablet; 3) had basic understanding on English to answer the questionnaire.

2) Interview: Open-ended questions are a type of qualitative survey that allows respondents to freely share their ideas. Moreover, they can describe in more details what they think or feel about the questions. The non-restrictive answers are very precious for depth data analysis. However, openended questions can be time consuming and require more data analysis [35]. To further understand our target users, a short interview session was conducted with three participants that meet the conditions of this study to determine the effects of using leisure technology in indirectly reducing the risk of Alzheimer's disease. Each interview session was carried out in a room and lasted about 1 hour. The procedures of the interview were very simple. First, the participant was required to play three popular applications namely SongArc (music),
Candy Crush Saga (puzzle), and PicsArt (art) which were available in Google Play Store. Once completed,.participants were required to play another application named Finger Paint With Sounds that was created by combining music and arts elements. Finally, the participants had to answer 12 questions created based on the subjective attributes as listed in Table IV.

\section{RESULTS}

The results section elaborates the outcome from the analysis of questionnaire survey and interview session. There were 60 and 3 respondents for the questionnaire and interview, respectively. The respondents were Malaysians aged 55 and above with most of them residing in Penang. The questionnaire results are divided into three sections in line with the questionnaire structure.

\section{A. Analysis of Questionnaire Results}

1) Section 1: Personal details and participant experience in the usage of leisure technology.

A total of $75 \%$ of the participants were in the age group of $50-60$ years old. In terms of gender analysis, this survey was answered by female (55\%) more than male (45\%). Moreover, $55 \%$ of the participants also showed more interest in playing the puzzle games than action and dancing games. Tobiasson [10] claimed that negative effects such as stress could make them unable to complete the game. Table V shows the factors contributing to elderly's motivation and interest to play puzzle games. Based on Table V, $45.5 \%$ of participants agreed that personal interest is the main factor that influenced their preference. In addition, $60 \%$ of participants also mentioned that they did not experience any side effects either physically or mentally after playing the puzzle games. The outcomes are also supported the previous statement by Hawthorn [36] that 
mentioned the physical ability of elderly people requires for a user friendly and simple interface in the game because their physical ability will gradually decline when their age increases.

This study also analyzed the amount of time elderly people spent on leisure technology. Based on the results from Fig. 2, about $58.3 \%$ of the participants agreed that they have 1 to 4 years' experience in using leisure technology while $43.3 \%$ from total respondents used leisure technology every day. Furthermore, about $40 \%$ of the participants used it more than twice a week, $11.7 \%$ used it once a week, $5 \%$ used it once a month and $(48.3 \%)$ used leisure technology for less than half hour. According to Saini et al. [37] games can improve basic abilities such as visual and attention tendency through play for a short time. Moreover, Science [38], also claimed that cognitive performances could improve if a person play games for an hour every day.

It is interesting to see whether elderly people are able to accomplish the games available in leisure technology. The analysis shows that about $90 \%$ of respondents mentioned that they were able to accomplish the tasks offered by leisure technology games (Fig. 3).

TABLE V. The BENEFITS OF LEISURE TECHNOLOGIES

\begin{tabular}{|l|l|l|}
\hline $\begin{array}{l}\text { Preferences in } \\
\text { Puzzle Games }\end{array}$ & $\begin{array}{l}\text { Number of } \\
\text { participants } \\
\text { preferences }\end{array}$ & $\begin{array}{l}\text { Effect of playing puzzle } \\
\text { games }\end{array}$ \\
\hline Personal interest & $\begin{array}{l}15 / 33 \text { participants } \\
(45.5 \%)\end{array}$ & $\begin{array}{l}\text { Body aches }=1 / 15(6.7 \%) \\
\text { Eye fatigue }=5 / 15(33.3 \%) \\
\text { None }=9 / 15(60.0 \%)\end{array}$ \\
\hline More challenging & $\begin{array}{l}\cdot 8 / 33 \text { participants } \\
(24.2 \%)\end{array}$ & $\begin{array}{l}\text { Eye fatigue }=3 / 8(37.5 \%) \\
\text { None }=5 / 8(62.5 \%)\end{array}$ \\
\hline $\begin{array}{l}\text { Easier to play } \\
\text { physically } \\
\text { (require less hand } \\
\text { movements) }\end{array}$ & $\begin{array}{l}5 / 33 \text { participants } \\
(15.2 \%)\end{array}$ & $\begin{array}{l}\text { Eye fatigue }=2 / 5(40 \%) \\
\text { None }=3 / 5(60 \%)\end{array}$ \\
\hline $\begin{array}{l}\text { Other } \\
\text { (Coordination of } \\
\text { brain and fingers) }\end{array}$ & $\begin{array}{l}3 / 33 \text { participants } \\
(9.1 \%)\end{array}$ & None $=3 / 3(100 \%)$ \\
\hline $\begin{array}{l}\text { Easier to play } \\
\text { mentally (require } \\
\text { less thinking or } \\
\text { brain power) }\end{array}$ & $\begin{array}{l}1 / 33 \text { participant } \\
(3.0 \%)\end{array}$ & None $=1 / 1(100 \%)$ \\
\hline $\begin{array}{l}\text { Other (Attractive) } \\
1 / 33 \text { participant } \\
(3.0 \%)\end{array}$ & None =1/1 (100\%) \\
\hline
\end{tabular}

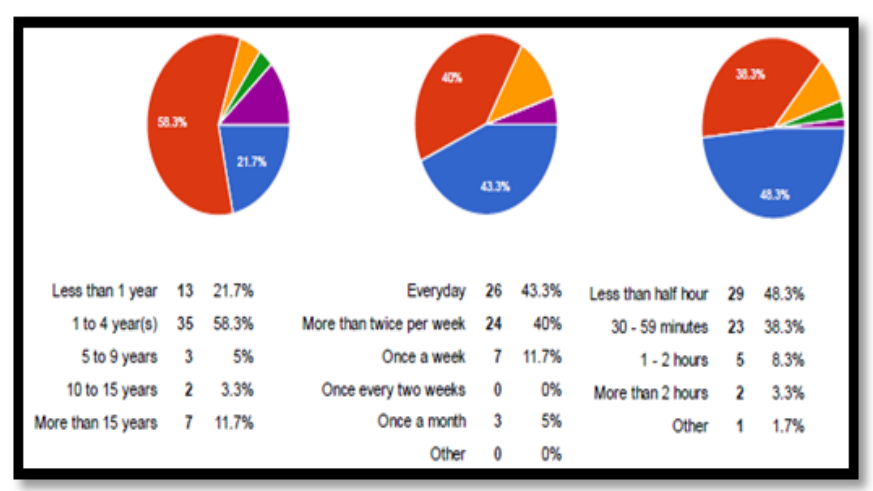

Fig. 2. Amount of time spent on leisure technology.

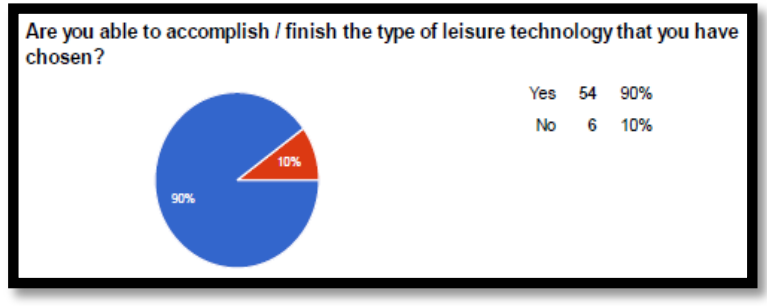

Fig. 3. Accomplishment leisure technology.

Then, the respondents also had been asking to answer whether they faced any physical or mental difficulty after using the leisure technology. As presented in Fig. 4, about $65 \%$ stated that they did not face any physical or mental difficulties, followed by $33.3 \%$ of eye fatigue, body aches $8.3 \%$, and Insomnia $3.3 \%$ while none of them felt headache and other types of side effects. According to Sixsmith and Gutman [1] games are a part of technology that developed for elderly people to allow them to experience enjoyable moments in their life. In addition, Cohen and Klunk [39] said leisure technology such as playing games is a relaxing method for elderly people to improve their cognitive thinking and memory to prevent Mild Cognitive Impairment (MCI), which leads to Alzheimer's disease at a later stage. The outcome of this study also showed that elderly people enjoyed the games with less difficulty such as eye fatigue and body aches. These types of drawbacks could be overcome by developing smart technology screens and embrace advance Human-Computer Interaction techniques during development of leisure technology application.

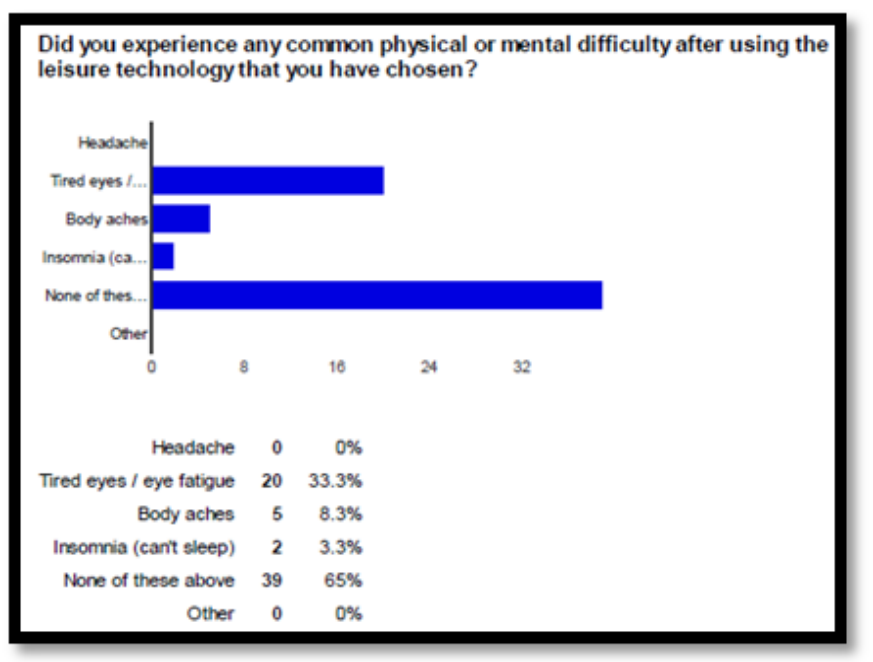

Fig. 4. Physical or mental difficulty after using leisure technology.

If you are given a choice, do you prefer traditional methods (leisure activities) to reduce the risk of Alzheimer's disease?
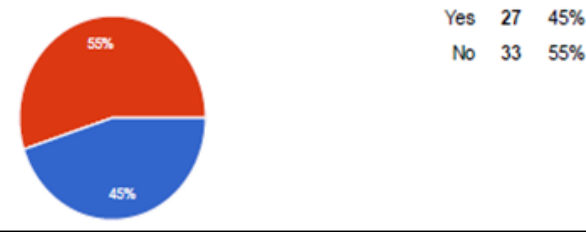

No $33 \quad 55 \%$

Fig. 5. Traditional methods vs leisure technology. 
Next, this study analyzed the preferences of participants of either traditional methods or leisure technology to reduce the risk of Alzheimer's disease. Fig. 5 shows that 33 out of 60 participants $(55 \%)$ preferred leisure technology to reduce the risk of Alzheimer's disease if they are given a choice between traditional methods and leisure technology. Moreover, Fig. 6 shows that 36 out of 60 participants $(60 \%)$ agreed that leisure technology can substitute traditional methods. The acceptance of leisure technology by more than half of the older respondents may be due to the convenience of the technology compared to most of the traditional leisure activities that require two or more players to play the game. This argument is supported by Lee et al. [40] who said that elderly people are willing to be exposed to technology and that they believe is more convenient and relaxing, compared to medical cognitive diagnosis, to detect $\mathrm{MCI}$, which is the early stage of Alzheimer's disease.

2) Section 2: User acceptance of leisure technology among elderly people.

This section focuses on participants' opinions of factors that may affect their likelihood to accept that leisure technology can reduce the risk of Alzheimer's disease. This section uses five-point scale format, where "1" indicates the worst factor and "5" indicates the best factor.

Confidence interval (CI) was used to estimate the sample size for this pilot study. Confidence interval refers to an expected value of mean that falls in the specific range of numbers in a standard normal distribution [41]. Point estimate is to estimate the population mean by using the sample mean. Thus, the confidence interval estimation is $\mu$ (Population mean) $=\overline{\mathrm{x}}$ (Sample mean) \pm a small sampling error. Confidence interval is normally calculated at the $95 \%$ confidence level [42], which was applied in this pilot study. One of the critical values lies exactly at the left region of the tail (lower limit) and another one lies exactly at the right region of the tail (upper limit) [41]. Thus, this is known as two-tailed tests. If the standard deviation is unknown and the sample size is greater than 30, the Z-test is used [41]. Since the population standard deviation $(\sigma)$ was unknown, we estimated the population standard deviation by finding $\mathrm{S}$, the sample standard deviation [41]. A list of formula is found in Table VI.

This study intends to determine the level of effectiveness of leisure technology to reduce the risk of Alzheimer's disease, and we obtained the result from our pilot study. A sample of 60 participants was gathered and asked to determine the level of effectiveness of leisure technology to reduce the risk of Alzheimer's disease on a five-point likert-scale through a survey, where 1 indicated "totally not effective" and 5 indicated "very effective". For instance when participants felt "moderate" which is 3 , the null hypothesis for this test was that the mean was equal to $3.0(\overline{\mathrm{x}}=3.0)$. Another hypothesis is that the mean is not equal $3.0(\overline{\mathrm{x}} \neq 3.0)$. If the mean fell under the region of acceptance (between the critical values of lower limit and upper limit), then this analysis concluded that the result is statistically significant at 0.05 level, or $95 \%$ confidence that leisure technology could effectively reduce the risk of Alzheimer's disease.

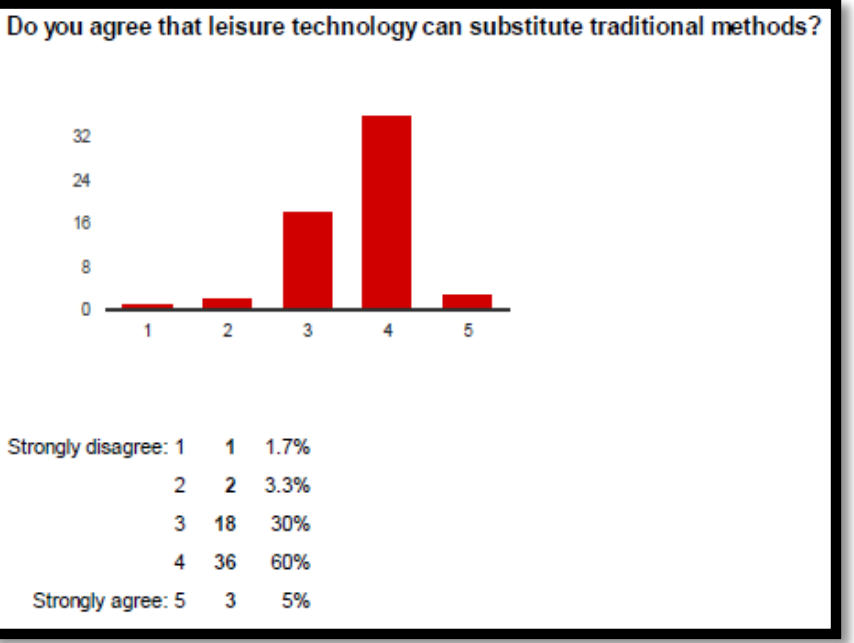

Fig. 6. Leisure technology can substitute traditional methods.

TABLE VI. A List of CALCULATION Formula in Pilot StUdy (ZIKMUND ET AL., 2012)

\begin{tabular}{|c|c|c|}
\hline Category & Formula & Glossary of Symbols \\
\hline Mean & $\mu=\frac{\sum_{i=1} X_{i}}{N}$ & $\begin{array}{l}X=\text { Total scores } \\
\mathrm{N}=\text { number of scoresc }\end{array}$ \\
\hline $\begin{array}{l}\text { Standard } \\
\text { deviation }\end{array}$ & $S=\sqrt{\frac{\sum\left(X_{i}-\bar{X}\right)^{2}}{n-1}}$ & $\begin{array}{l}\mathrm{X}=\text { Total scores } \\
\mathrm{n}=\text { Number of scores } \\
\overline{\mathrm{x}}=\text { Sample mean }\end{array}$ \\
\hline $\begin{array}{l}\text { Confidence } \\
\text { interval }\end{array}$ & $\begin{array}{l}\bar{X} \pm Z \frac{S}{\sqrt{n}} \\
\mu \text { (Population mean) }=\bar{x} \\
\text { (Sample mean) }\end{array}$ & $\begin{array}{l}\mathrm{n}=\text { Number of scores } \\
\mathrm{S}=\text { Standard deviation } \\
\mathrm{Z}=\mathrm{Z} \text {-value }(1.96)\end{array}$ \\
\hline $\begin{array}{l}\text { Critical Value } \\
\text { (lower limit) }\end{array}$ & $\mu-Z \frac{S}{\sqrt{n}}$ & $\begin{array}{l}\mu=\text { Population mean } \\
\mathrm{n}=\text { Number of scores } \\
\mathrm{S}=\text { Standard deviation } \\
Z=Z \text {-value }(1.96)\end{array}$ \\
\hline $\begin{array}{l}\text { Critical Value } \\
\text { (upper limit) }\end{array}$ & $\mu+Z \frac{S}{\sqrt{n}}$ & $\begin{array}{l}\mu=\text { Population mean } \\
\mathrm{n}=\text { Number of scores } \\
\mathrm{S}=\text { Standard deviation } \\
\mathrm{Z}=\mathrm{Z} \text {-value (1.96) }\end{array}$ \\
\hline
\end{tabular}


TABLE VII. DATA ANALYSIS ON ADAPTATION AND IMPORTANCE OF LEISURE TECHNOLOGY

\begin{tabular}{|l|l|l|l|l|l|l|}
\hline Hypothesis & $\begin{array}{l}\text { Null } \\
\text { hypothesis }\end{array}$ & $\begin{array}{l}\text { Mean, } \\
\mathbf{x}\end{array}$ & $\begin{array}{l}\text { Standard } \\
\text { deviation }\end{array}$ & $\begin{array}{l}\text { Critical value } \\
\text { (lower limits) }\end{array}$ & $\begin{array}{l}\text { Critical value ( } \\
\text { upper limits) }\end{array}$ & $\begin{array}{l}\text { Hypothesis } \\
\text { accepted or } \\
\text { rejected? }\end{array}$ \\
\hline $\begin{array}{l}\text { Leisure technology a convenient and relaxing method } \\
\text { to reduce the risk of Alzheimer's disease }\end{array}$ & 3.50 & 3.87 & 0.62 & 3.71 & 4.03 & Rejected \\
\hline It is easy to adapt to leisure technology & 3.50 & 3.65 & 0.68 & 3.48 & 3.82 & Accepted \\
\hline $\begin{array}{l}\text { I can adapt faster to leisure technology using an } \\
\text { electronic device }\end{array}$ & 3.50 & 3.68 & 0.60 & 3.53 & 3.83 & Accepted \\
\hline
\end{tabular}

Based on Table VII, one of the hypotheses was rejected because the mean (3.87) was higher than the null hypothesis (3.50). Thus, we cannot conclude that the statement was rejected. In fact, this result shows that there was an increase in the number of elderly people, who feel that leisure technology is a convenient and relaxing method to reduce the risk of Alzheimer's disease. The rest of them were accepted and thus this study is $95 \%$ confident in agreeing to that particular statement or the result is statistically significant at 0.05 level.

We further analysed how important the following statements were in influencing their acceptance of leisure technology, which can reduce the risk of Alzheimer's disease (Table VIII).

Based on Table VIII, all of the hypotheses are accepted and thus this study is $95 \%$ confident in agreeing to that particular statement or the results are statistically significant at 0.05 level. Moreover, in order to understand which criteria was the most favoured by the participants, we ranked each of these criteria based on the mean $(\overline{\mathrm{x}})$ (Fig. 7).

Based on Fig. 7, the first ranked, where there were 39 out of 60 participants $(65 \%)$, who selected user friendly interface in leisure technology, was simple to play (mean $=4.17$ ). The null hypothesis was 3.5, which was not between the critical value of lower (4.01) and upper (4.33) limits, and thus it was rejected. In fact, the actual means from the results were higher than the null hypothesis, and this shows that there was an increase in the number of elderly people who were seeking user friendly interface. This supports the statement that a user friendly game should be widely available to elderly people so that they can easily accept the change or new methodology [9].

The second in ranking was the sharing feature. There were 29 out of 60 participants $(48.3 \%)$, who selected the sharing feature in leisure technology (mean $=3.33$ ) so that they can socialize with each other, hence increasing social interaction. One of the participants stated in the feedback form that if individuals are not able to undertake leisure technology on their own due to whatever constraints they may have, there should be avenues for group formation or team interaction which can help the individuals achieve any form of leisure technology they choose. Thus, if a user wants to use the leisure technology but require assistance to use it, social interaction such as instant messaging in the proposed leisure technology conceptual design is important in order for other users to assist that particular user. Another feedback from another participant was, playing around with friends will be more fun. If that participant plays alone using electronic devices, it will be boring. The null hypothesis was 3.5, which was between the critical value of lower (3.12) and upper (3.54) limits, and thus it was accepted. These results support the statement by Sixsmith and Gutman [1] that games allow social interaction and learning through an enjoyable experience for everybody. Thus, social networking feature is important in the proposed leisure technology conceptual design in order to increase the level of social interaction among elderly people.

TABLE VIII. DATA ANALYSIS ON ADAPTATION AND IMPORTANCE OF LEISURE TECHNOLOGY

\begin{tabular}{|c|c|c|c|c|c|c|}
\hline Hypothesis & $\begin{array}{l}\text { Null } \\
\text { hypothesis }\end{array}$ & $\begin{array}{l}\text { Mean, } \\
\overline{\mathbf{x}}\end{array}$ & $\begin{array}{l}\text { Standard } \\
\text { deviation }\end{array}$ & $\begin{array}{l}\text { Critical value } \\
\text { (lower limits) }\end{array}$ & $\begin{array}{l}\text { Critical value } \\
\text { (upper limits) }\end{array}$ & $\begin{array}{l}\text { Hypothesis } \\
\text { accepted or } \\
\text { rejected? }\end{array}$ \\
\hline $\begin{array}{l}\text { Knowledge of the changes before implementation of } \\
\text { new method is important for elderly acceptance to } \\
\text { leisure technology }\end{array}$ & 3.50 & 3.28 & 0.78 & 3.08 & 3.50 & Accepted \\
\hline $\begin{array}{l}\text { Influence from others is the reason for elderly } \\
\text { acceptance to leisure technology }\end{array}$ & 3.50 & 3.20 & 0.82 & 2.99 & 3.41 & Rejected \\
\hline $\begin{array}{l}\text { Elderly mus have previous experience in order to } \\
\text { adapt to leisure technology }\end{array}$ & 3.50 & 3.08 & 0.72 & 2.90 & 3.26 & Rejected \\
\hline $\begin{array}{l}\text { Cost of the electronic devices affect elderly } \\
\text { acceptance to leisure technology }\end{array}$ & 3.50 & 3.18 & 0.77 & 2.99 & 3.37 & Rejected \\
\hline Leisure technology must be user friendly or simple. & 3.50 & 4.17 & 0.62 & 4.01 & 4.33 & Rejected \\
\hline Leisure technology must include reward program & 3.50 & 3.20 & 0.94 & 2.96 & 3.44 & Rejected \\
\hline $\begin{array}{l}\text { Leisure technology must have information sharing } \\
\text { features (such as Facebook) }\end{array}$ & 3.50 & 3.33 & 0.82 & 3.12 & 3.54 & Accepted \\
\hline
\end{tabular}




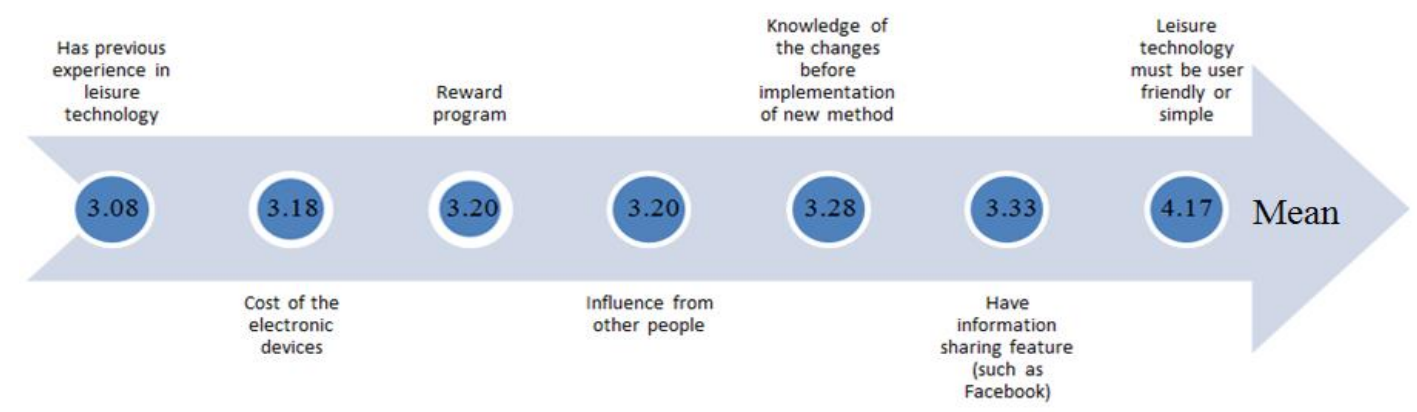

Fig. 7. Ranking based on mean on criteria in leisure technology.

The third in ranking $($ mean $=3.28)$ was the requirement to understand the knowledge of the changes before implementation of new method or proposing an enhanced version of leisure technology, ranked by 25 out of 60 participants $(41.7 \%)$. The null hypothesis was 3.5 , which was between the critical value of lower (3.08) and upper (3.50) limits, and thus it was accepted. This result supports the statement by Eisma et al. [43] that introduction of new methodology for elderly people to reduce the risk of Alzheimer's disease is important in order to allow them to discover the importance of new technology that has a positive impact in their lives. The amount of knowledge in every individual is different and thus each of them has different opinion on the acceptance of leisure technology to reduce the risk of Alzheimer's disease.

Reward program was ranked at number 4 , with the mean $=$ 3.20. Twenty-seven out of 60 participants $(45 \%)$ stated that the reward program was moderately " 3 " on influencing them on the acceptance of leisure technology. The null hypothesis was 3.5, which was not between the critical value of lower (2.96) and upper (3.44) limits, and thus it was rejected. These results show that there were different types of opinions by participants. One of the feedbacks by participants stated that reward program should be based on internal game rewards only such as daily check-ins to earn extra points. Another feedback by another participant stated that it is hard to collect points from games and exchange for real life vouchers or coupons in a reward program. Instead of doing so, it will be better if the proposed conceptual design could have in-game rewards to collect and exchange for in-game stuff. For example, daily login rewards giving free gems/coins/tickets to exchange for in game items, such as "life, hearts or something similar". Thus, since the null hypothesis was rejected and there were feedbacks for improvement in this reward program feature, the proposed conceptual design proposes in-game reward instead of collecting points in-game to exchange for cash vouchers in participating outlets.

Influence from other people on the usage of leisure technology had been ranked the same (rank no. 4) as reward program feature, where 24 out of 60 participants (40\%), mean $=3.20$, stated that influence from other people on the acceptance of leisure technology was moderately " 3 ". The null hypothesis was 3.5 , which was not between the critical value of lower (2.99) and upper (3.41) limits, and thus it was rejected. This result shows that each elderly person had a different perception on the usage of leisure technology to reduce the risk of Alzheimer's disease. One of the participants feedback stated that, the level of leisure technology should be reviewed occasionally to ascertain its effectiveness because it might result in confusion and lack of interest among elderly people due to technicalities and not all of them are hi-tech savvy. Thus, this supports the result that not all elderly people were being influence by others to use leisure technology, but it was based on their personal interest and the technical performance of the leisure technology.

The second last ranking was regarding the cost of the electronic devices. Majority of the participants, 26 out of 60 participants $(43.3 \%)$, stated that the cost of the electronic devices was moderately " 3 " in influencing their acceptance of a new methodology $($ mean $=3.18)$. The null hypothesis was 3.5 , which was not in between the critical value of lower (2.99) and upper (3.37) limits, and thus it was rejected. The results show that the cost of electronic devices did not affect participants on the acceptance of leisure technology because they can afford to purchase and use them. This supports the statement by Coughlin [44] that there is an increase in the usage of technology among people who age 50 years and above because they have better income and they can afford to purchase and use them. According to Lee and Groves [5], everybody can adapt to technology easily regardless of age and it is impossible to perform daily tasks without it. Moreover, if a person understands how to use the technology well, it will make a person's life easier. However, there is a minor challenge in terms of understanding individual financial plan because this survey was taken from participants who were staying in city areas and had middle class income. In Malaysia, there has been an increase in the rate of unemployment and inflation, and thus affecting the economy markets [45]. This also gives a negative impact on consumers such as in changing their daily consumption and purchasing habits [45]. During a recession or economic downturn, consumers tend to spend only on necessity items such as food [46].

The last ranking was about previous experience on the usage of leisure technology. Majority of the participants, 24 out of 60 participants (40\%), stated that having previous experience on the usage of leisure technology was moderately " 3 " in influencing their acceptance of a new methodology $($ mean $=3.08)$. The null hypothesis was 3.5 , which was not between the critical value of lower (2.90) and upper (3.26) limits, and thus it was rejected. Thus, this result shows that prior experience of using leisure technology does not affect their acceptance of using leisure technology. Thus, these results 
support the statement by Lee and Groves [5], where technology instruments such as computers, tablets, mobile phone, or any other electronic devices, are easily adapted by people in their daily living. People can hardly perform daily tasks if technology does not exist. It is important that people should know how to use technology in a correct way in order to obtain the most benefits from it [5].

\section{3) Section 3: Feedback}

This section shows the feedback by participants on this proposed leisure technology conceptual design.

Fig. 8 shows that participants preferred a combination of various features in the proposed leisure technology conceptual design. This result was also supported by Table IX that compares the benefits of using different types of leisure technologies.

To determine the participants' overall experiences in using leisure technology to reduce the risk of Alzheimer's disease, Fig. 9 shows that 14 out of 60 participants $(23.3 \%)$ selected "3", 44 out of 60 participants (73.3\%) selected " 4 ", and 2 out of 60 participants $(3.3 \%)$ selected " 5 ". Based on this sample of size of $n=60$, the null hypothesis was 3.50, where the population stated that leisure technology can effectively reduce the risk of Alzheimer's disease. However, the critical values for lower and upper limits were between 3.68 and 3.92. Since the mean (3.80) was higher than the null hypothesis, this result shows that there was an increase in the number of elderly people who accepted that leisure technology can reduce the risk of Alzheimer's disease. Thus, we are 95\% confident that leisure technology can effectively reduce the risk of Alzheimer's disease.

Lastly, the acceptance of leisure technology among elderly people allowed them to volunteer referring leisure technology to their friends or family in order to reduce the risk of Alzheimer's disease (Fig. 10).

\section{B. Interview}

Three participants had different perceptions on the usage and user acceptance of leisure technology among elderly people. Overall, they agreed that leisure technology could improve their cognitive abilities. Different types of leisure technology provide different types of benefits in terms of cognitive abilities. Thus, these results validate the findings from literature that leisure technology could reduce the risk of Alzheimer's disease. Table $\mathrm{X}$ lists down in details on the interview questions and answers.

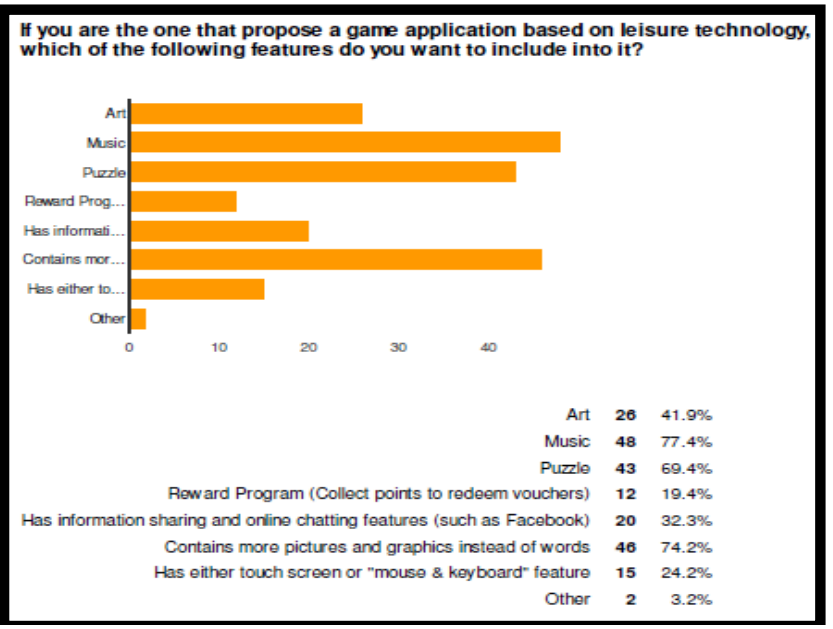

Fig. 8. Leisure technology can substitute traditional methods.

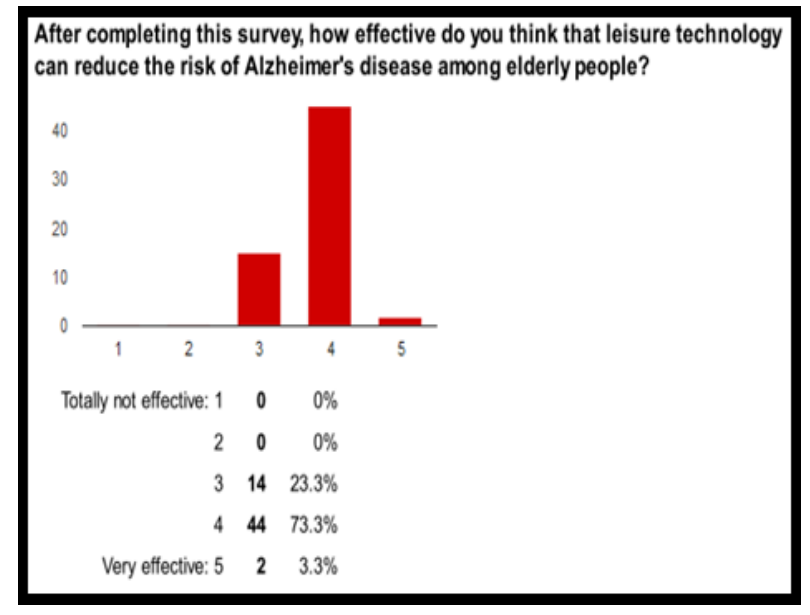

Fig. 9. Effectiveness of leisure technology to reduce the risk of Alzheimer's disease.

TABLE IX. COMPARISON ON BENEFITS OF LEISURE TECHNOLOGY BASED ON LITERATURE REVIEW AND SURVEY RESULTS

\begin{tabular}{|c|c|c|}
\hline $\begin{array}{l}\text { Types of Leisure } \\
\text { Technology }\end{array}$ & Benefits for Elderly People (Based on Literature Review) & Benefits for Elderly People (Based on Survey Results) \\
\hline Art & $\begin{array}{l}\text { - Able to stay active by thinking creatively on what to draw. } \\
\text { - Increase the level of social interaction. } \\
\text { - Reduce aggressive behavior. }\end{array}$ & $\begin{array}{l}\text { - Think more creatively. } \\
\text { - Improve memory skills / Trigger back past memories. } \\
\text { - Improves visual memory - Able to remember pictures, sequence } \\
\text { of letters in words, appearance. }\end{array}$ \\
\hline Music & $\begin{array}{l}\text { - Trigger back their memories and improve memory skills. } \\
\text { - Improve creativity, language skills and able to control their } \\
\text { emotions. } \\
\text { - Able to share their feelings with other people and } \\
\text { communicate with each other properly. }\end{array}$ & $\begin{array}{l}\text { - Increase the level of social interaction. } \\
\text { - Reduce aggressive behavior. } \\
\text { - Improve memory skills / Trigger back past memories. } \\
\text { - Improves visual memory - Able to remember pictures, sequence } \\
\text { of letters in words, appearance. }\end{array}$ \\
\hline Puzzle & $\begin{array}{l}\text { - Improves visuospatial skill. } \\
\text { - Improves the level of IQ and reading ability } \\
\text { - Improves visual memory. }\end{array}$ & $\begin{array}{l}\text { - Think more creatively. } \\
\text { - Increase the level of social interaction. } \\
\text { - Improve memory skills / Trigger back past memories. } \\
\text { - Improves visual memory - Able to remember pictures, sequence } \\
\text { of letters in words, appearance. }\end{array}$ \\
\hline
\end{tabular}


TABLE X. INTERVIEW QUESTIONS AND ANSWERS

\begin{tabular}{|c|c|c|c|c|}
\hline No. & Questions & Participant no. 1 & Participant no. 2 & Participant no. 3 \\
\hline 1. & $\begin{array}{l}\text { After playing the art application, is } \\
\text { there any improvement in your } \\
\text { memory skills? If yes, can you } \\
\text { explain in detail? }\end{array}$ & $\begin{array}{l}\text { Yes, there is. I feel it is colorful and } \\
\text { can sharpen my mind, which allows } \\
\text { me to think creatively. }\end{array}$ & $\begin{array}{l}\text { I rarely play art application and } \\
\text { yes, it stimulates my brain and } \\
\text { allows me to think out of the } \\
\text { box. }\end{array}$ & $\begin{array}{l}\text { Yes, it helps me to have } \\
\text { better decision making. }\end{array}$ \\
\hline 2. & $\begin{array}{l}\text { After using the music application, is } \\
\text { there any improvement in your } \\
\text { memory skills? If yes, can you } \\
\text { explain in detail? }\end{array}$ & $\begin{array}{l}\text { Yes, there is. I feel that the music is } \\
\text { soothing, which can calm me down, } \\
\text { control my temper and release my } \\
\text { stress. }\end{array}$ & $\begin{array}{l}\text { Yes, there is. I can feel more } \\
\text { relaxed and able to think better } \\
\text { to solve problems. }\end{array}$ & $\begin{array}{l}\text { Yes, my mind feels more } \\
\text { refreshed and clear. }\end{array}$ \\
\hline 3. & $\begin{array}{l}\text { After the playing puzzle } \\
\text { application, is there any } \\
\text { improvement in your memory } \\
\text { skills? If yes, can you explain in } \\
\text { detail? }\end{array}$ & $\begin{array}{l}\text { Yes, there is. I feel it is more } \\
\text { challenging compared to other } \\
\text { types. Puzzle can improve my IQ } \\
\text { and allow me to think harder. }\end{array}$ & $\begin{array}{l}\text { Yes, there is. It makes me think } \\
\text { harder to move the next step in } \\
\text { the game. I feel addicted to this } \\
\text { game because it is attractive } \\
\text { due to the in-game rewards. }\end{array}$ & $\begin{array}{l}\text { Yes, I feel there is more } \\
\text { finger coordination and it } \\
\text { challenges my mind. }\end{array}$ \\
\hline 4. & $\begin{array}{l}\text { Did you experience any common } \\
\text { physical or mental difficulty after } \\
\text { playing any of these games? If yes, } \\
\text { what is that? }\end{array}$ & $\begin{array}{l}\text { I did not experience any difficulty } \\
\text { after playing all of the three games. }\end{array}$ & None. & None. \\
\hline 5. & $\begin{array}{l}\text { Based on these three categories you } \\
\text { played, did they provide the same } \\
\text { benefits or different benefits in } \\
\text { terms of improving your memory? }\end{array}$ & $\begin{array}{l}\text { In my opinion, these three } \\
\text { categories provided different } \\
\text { benefits to improve my memory. }\end{array}$ & $\begin{array}{l}\text { Yes, there were different } \\
\text { benefits. Art helped me to think } \\
\text { creatively, music could calm } \\
\text { me down and puzzle allowed } \\
\text { me to think harder. }\end{array}$ & $\begin{array}{l}\text { They provided different types } \\
\text { of benefits because these } \\
\text { games required different } \\
\text { types of thinking skills to } \\
\text { play. }\end{array}$ \\
\hline 6. & $\begin{array}{l}\text { Based on these three categories you } \\
\text { played, which type (art, music and } \\
\text { puzzle) do you prefer the most? } \\
\text { Why? }\end{array}$ & $\begin{array}{l}\text { I prefer puzzle because I am } \\
\text { seeking something that can } \\
\text { challenge my mind to maintain my } \\
\text { brain functions. }\end{array}$ & $\begin{array}{l}\text { I prefer puzzle because it } \\
\text { allows me to think harder than } \\
\text { normal. This is useful when } \\
\text { solving problems. }\end{array}$ & $\begin{array}{l}\text { I prefer puzzle because it } \\
\text { requires me to complete } \\
\text { certain tasks to move to the } \\
\text { next level of difficulty, which } \\
\text { attracts me. }\end{array}$ \\
\hline 7. & $\begin{array}{l}\text { After playing music }+ \text { art } \\
\text { application, do you feel any } \\
\text { different compared to playing just } \\
\text { one type of application? }\end{array}$ & $\begin{array}{l}\text { I feel it was more challenging and } \\
\text { brain stimulating when playing } \\
\text { music + art application, compared } \\
\text { to just one type. }\end{array}$ & $\begin{array}{l}\text { I feel it was more interesting } \\
\text { and fun. }\end{array}$ & $\begin{array}{l}\text { Yes, there were differences. } \\
\text { For example, it was more } \\
\text { interesting to play because it } \\
\text { had two features (art and } \\
\text { music). }\end{array}$ \\
\hline 8. & $\begin{array}{l}\text { Did you experience any common } \\
\text { physical or mental difficulty after } \\
\text { playing music + art? If yes, what is } \\
\text { that? }\end{array}$ & $\begin{array}{l}\text { I did not experience any difficulty } \\
\text { after playing it. }\end{array}$ & None. & None. \\
\hline 9. & $\begin{array}{l}\text { If you are the one proposing a } \\
\text { conceptual design, which type (art, } \\
\text { music and puzzle) do you want to } \\
\text { include? Why? }\end{array}$ & $\begin{array}{l}\text { If possible, I prefer all of these } \\
\text { categories, which are art, music and } \\
\text { puzzle, to be included in the } \\
\text { conceptual design since all of them } \\
\text { provide different types of benefits. }\end{array}$ & $\begin{array}{l}\text { I prefer music and art as played } \\
\text { just now because it is easier to } \\
\text { play and soothing. }\end{array}$ & $\begin{array}{l}\text { In my opinion, I prefer } \\
\text { puzzle and music because I } \\
\text { myself like to play puzzle } \\
\text { game. With additional music } \\
\text { feature, this can make me } \\
\text { more relaxed. }\end{array}$ \\
\hline 10. & $\begin{array}{l}\text { If you score badly in the game, do } \\
\text { you want a system that can remind } \\
\text { you of medical check up? If yes, } \\
\text { why? If no, why? }\end{array}$ & $\begin{array}{l}\text { Yes, I want a system that can } \\
\text { remind me of medical check up } \\
\text { because I might forget and might } \\
\text { not realize that I may experience } \\
\text { early symptoms of Alzheimer's } \\
\text { disease. I always rely on a reminder } \\
\text { system such as calendar in my } \\
\text { phone. }\end{array}$ & $\begin{array}{l}\text { Yes, because reminder is a } \\
\text { necessary item for daily } \\
\text { performance. I tend to forget } \\
\text { things easily when I grow } \\
\text { older. }\end{array}$ & $\begin{array}{l}\text { Yes, I can understand what is } \\
\text { happening in my brain to } \\
\text { prevent any disease related to } \\
\text { the brain. }\end{array}$ \\
\hline 11. & $\begin{array}{l}\text { Do you want a game that can store a } \\
\text { history of scores in order to trace } \\
\text { and understand better your } \\
\text { cognitive performance? If yes, } \\
\text { why? If no, why? }\end{array}$ & $\begin{array}{l}\text { Yes, it will be easier for me to trace } \\
\text { my performance because I might } \\
\text { forget it in the future. }\end{array}$ & $\begin{array}{l}\text { Yes, storing game scores can } \\
\text { allow me to understand my } \\
\text { performance. }\end{array}$ & $\begin{array}{l}\text { Yes, I can understand my } \\
\text { brain performance better. }\end{array}$ \\
\hline 12. & $\begin{array}{l}\text { Do you have any suggestion for this } \\
\text { study? }\end{array}$ & $\begin{array}{l}\text { This study will be challenging } \\
\text { because most elderly people in } \\
\text { Malaysia are not } 100 \% \text { adaptive to } \\
\text { technology, especially in rural } \\
\text { areas. In order to increase the } \\
\text { acceptance rate of using technology, } \\
\text { it is important that the proposed } \\
\text { conceptual design is user friendly, } \\
\text { and able to meet their cost } \\
\text { expectation. }\end{array}$ & $\begin{array}{l}\text { This is an interesting topic and } \\
\text { it is new in Malaysia. I wish all } \\
\text { people in Malaysia can } \\
\text { recommend this to other elderly } \\
\text { people and to teach each other } \\
\text { to accept the usage of leisure } \\
\text { technology to prevent } \\
\text { Alzheimer's disease. }\end{array}$ & $\begin{array}{l}\text { Technical and security issues } \\
\text { for this proposal need to be } \\
\text { reviewed in order to maintain } \\
\text { its performance for long term } \\
\text { usage. }\end{array}$ \\
\hline
\end{tabular}




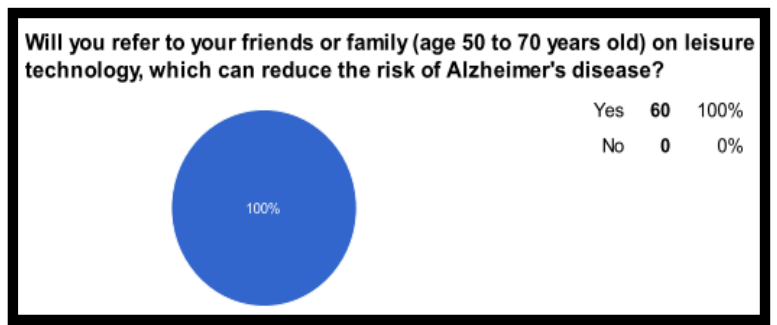

Fig. 10. Will you refer leisure technology?

\section{Summary of Analysis Results}

The development of leisure technology application should be based on the results of questionnaires and interview in this study. Based on the data analysis of the questionnaire responses and interview, different types of leisure technologies, namely, art, music and puzzle, provide different types of benefits. Moreover, based on participants' feedback, they are looking for an application that is developed by integrating the elements of art, music and puzzle as they can fully experience the benefits of these leisure technologies. The combination of three types of leisure technologies (art, music and puzzle) is believed to enhance the functions of leisure technology to reduce the risk of Alzheimer's disease among elderly people. In order to increase the user acceptance of user technology, several criteria such as user friendliness, in-game reward program, reminder system, social networking and compatibility on electronic devices such as tablets, mobile phones, desktop computers and laptops should be considered. Therefore, it is essential for developer to consider the development of leisure technology by integrating the elements noted above so that the technology is able to fulfill the needs of elderly people.

\section{APPLICATION DEVELOPMENT}

The application development section discusses the proposed conceptual design of leisure technology for elderly people.

\section{A. System Architecture}

The game engine acts as a middleware to connect user with the system to allow user to understand the usage of it. Since the proposed conceptual design is compatible on desktop computer, laptop, mobile phone and tablet, the engine of the game would be developed for Windows, IOS and Android platforms. Application Program Interface (API) connects individual software components based on a set of procedures and protocols [47]. Server and database connect users through internet connection by storing their game scores, the cognitive reports of users and allowing social networking services (Fig. 11).

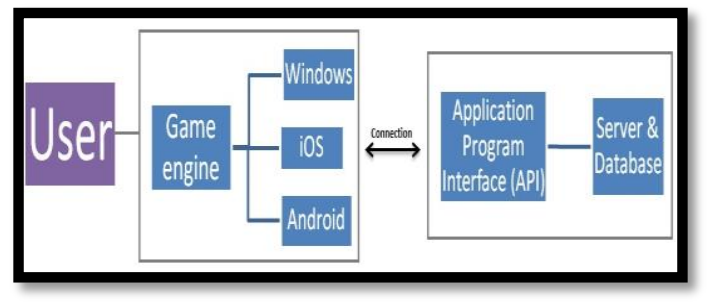

Fig. 11. System architecture.

\section{B. Conceptual Design for Hybrid Application that Contains Art, Music, Puzzle}

The proposed conceptual design of leisure technology is named IronBrain. As mentioned earlier, some elderly people prefer to use touch screen and the rest like to use mouse and keyboard to communicate with game applications. Therefore, the development of IronBrain will emulate those interfaces in order to enhance the accessibility of elderly people.

Fig. 12 showed a paintball game where the user needs to connect 3 or more paintballs to get the points. Elderly people that play this game need to observe and think of how to connect the paintballs better to get high points within a short time. In other words, the sharpness of eye-cognitive coordination of elderly people is essential to make them play better.

Users can upload their favourite music from their electronic devices, and save them in the game account (Fig. 13). They can also use Spotify application to select the desired songs. By integrating the musical elements in the game application, the elderly people can enjoy playing the games and improve their cognitive functions indirectly as active brain functionality may hinder Alzheimer diseases.

Fig. 14 shows the main screen of the leisure technology conceptual design. General login requires username and password in order to create an account to save game scores, coins, music and others. Thus, this can enable a person to have access to their account wherever they are as long as they have an electronic device.

In order to encourage elderly people to play, they can only use in-game coins to purchase in-game items such as game boosters to use for the next stage (Fig. 15). Thus, they are required to earn bonus coins by matching the same shape in the game (Fig. 16).

The reward program will provide several game boosters to encourage player to play the game easily. The reward program depends on the performances of players on weekly and monthly basis. The users can also watch their friends' scores and rankings. Moreover, they can send game heart to other friends (limited one per day) and send daily quotes or messages to interact with each other. By inviting a friend to play this game, they can earn more coins and have higher social interaction.

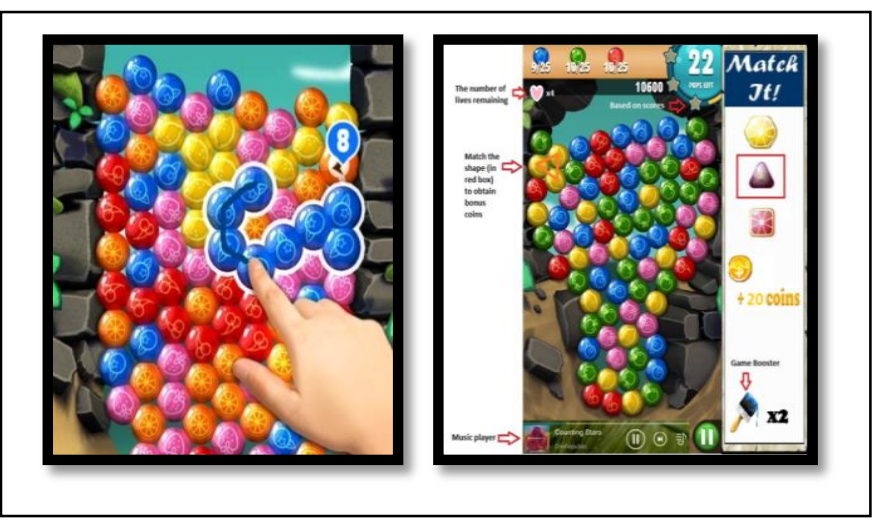

Fig. 12. Game interface contains art, music puzzle features [48]. 


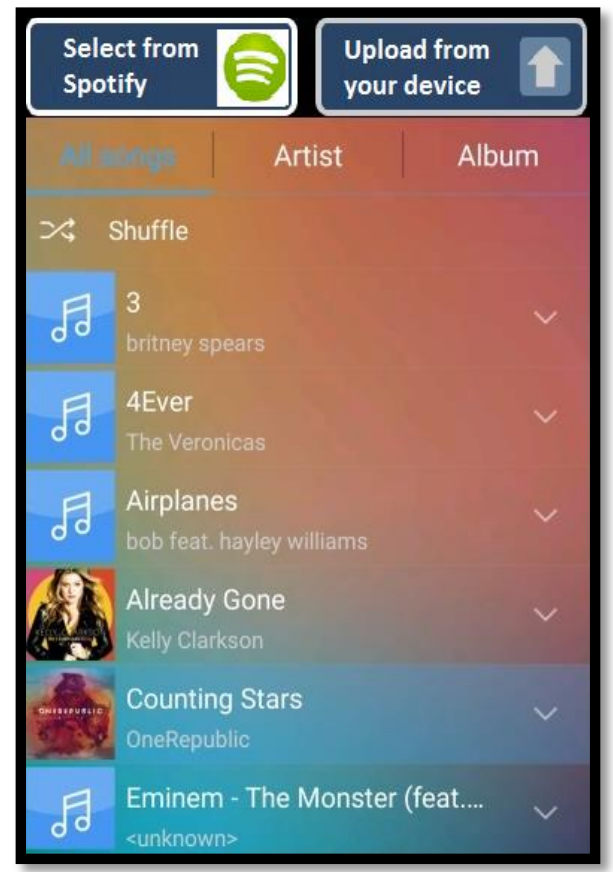

Fig. 13. Upload your favorite music and save in this game to play.

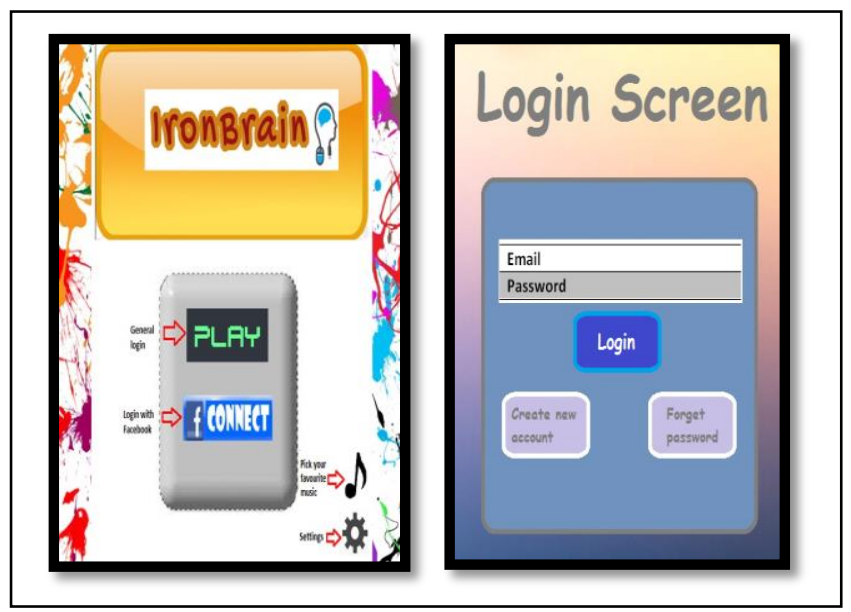

Fig. 14. Main screen and login screen of the conceptual design.

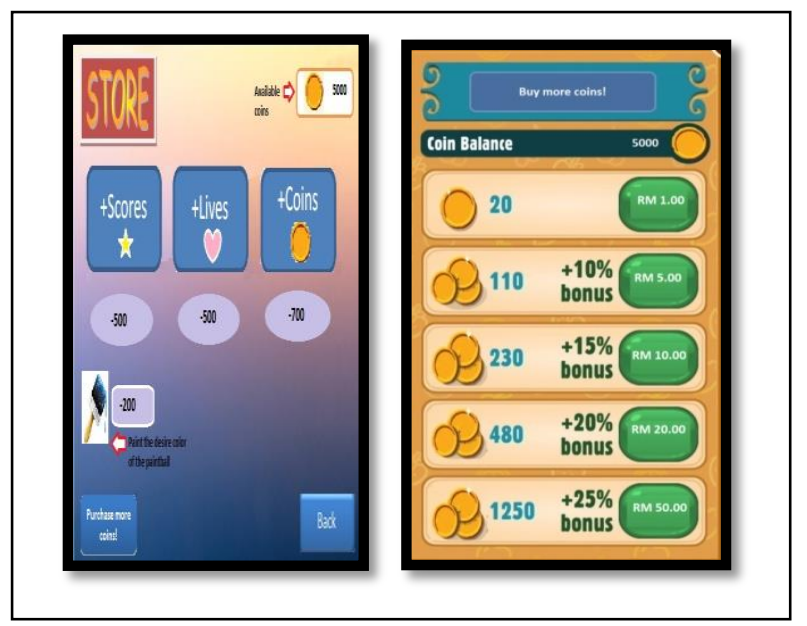

Fig. 15. Game coins can purchase in-game items.

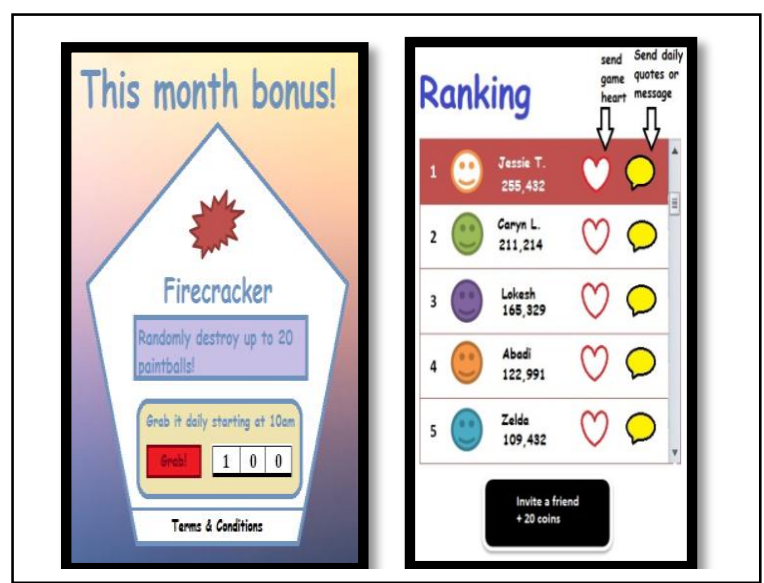

Fig. 16. Monthly bonus item.

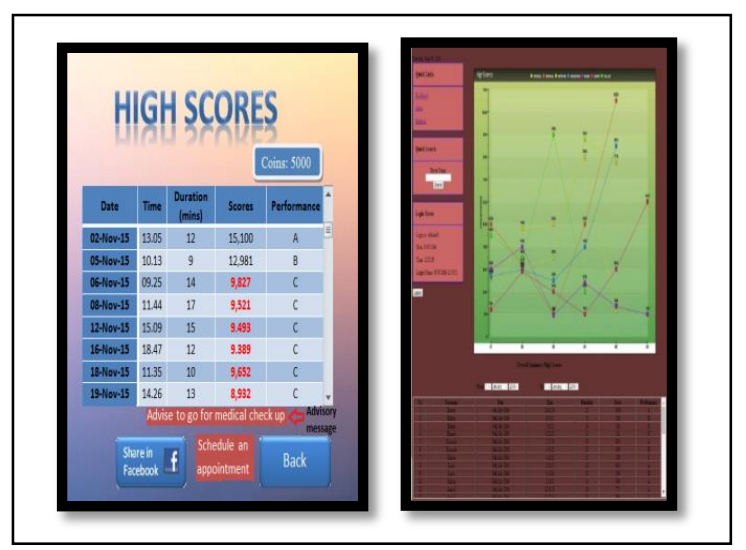

Fig. 17. Overview of game scores history.

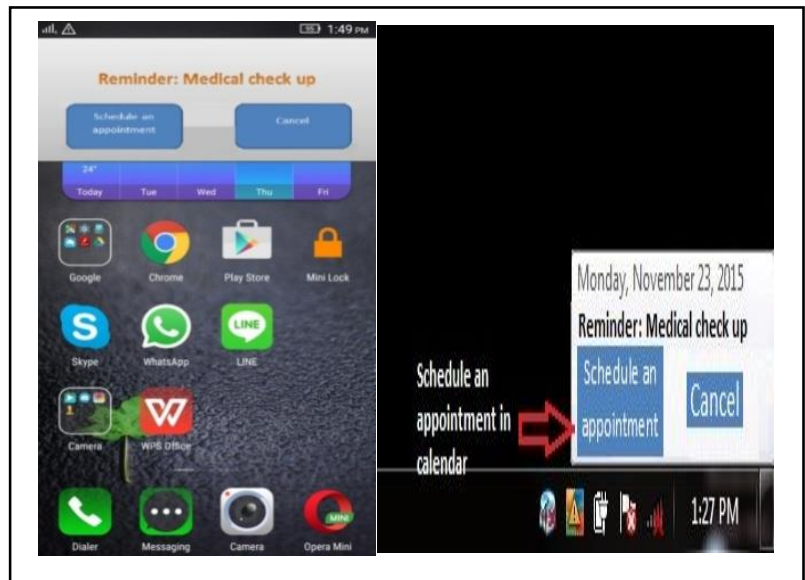

Fig. 18. Reminder pop-up screen on laptop and mobile phone.

In order to keep track on their performance, users can trace their scores history (Fig. 17). The performance measure is based on the duration of playing time and high scores obtained in the game. The score in red font in Fig. 17 indicates that the player has to be aware because these indicators are below the average score or duration. If elderly people score badly continuously for one month, the leisure technology conceptual design serves as an indicator to warn them that they should go for a medical check-up in order to determine if there are any symptoms of Alzheimer's disease. The right side image shows 
details of players' performances that can be observed by medical practitioners for further diagnostics. Users can schedule an appointment for medical check-up in the calendar apps so that they will not miss the diagnostic session (Fig. 18).

\section{CONCLUSION AND FUTURE WORK}

This study has yielded different types of results from the survey and interview, which helps us better understand how leisure technology can reduce the risk of Alzheimer's disease and the user acceptance of leisure technology among elderly people. The results from survey show that $90 \%$ of the participants stated that there were improvements in cognitive abilities after using leisure technology and $98.4 \%$ of the participants (moderate " 3 " to very easy " 5 ") stated that they can adapt to leisure technology. Moreover, all of the participants will recommend the usage of leisure technology to their friends and families. On the other hand, the results from the interview show that they agreed that different types of leisure technology provide different types of benefits, which can improve their cognitive abilities. The enhanced version of leisure technology conceptual design by combining puzzle, music and art is proposed based on the results from the survey and interview. In addition, it contains features such as user friendly interface, in-game rewards, reminder system and social networking, to encourage elderly people to play. Future work for this study is to establish a Healthcare Information System (HIS) in this proposed conceptual design. This can link to healthcare providers so that they can monitor the health conditions of their patients based on the overall scores. Each patient is required to register his or her preferred doctor to monitor the health conditions. For example, if a patient scores badly for 1 month and forgets to schedule an appointment personally, the healthcare provider will contact the patient automatically to remind them of the medical checkup and schedule an appointment. In addition, healthcare practitioner can monitor the patient's health condition during treatment period.

\section{ACKNOWLEDGMENT}

We are grateful for the voluntarity of our respondents and we thank Universiti Sains Malaysia for supporting this project.

\section{REFERENCES}

[1] Sixsmith, A., \& Gutman, G. (2013). Technologies for Active Aging (Vol. 9): Springer Science \& Business Media.

[2] Burns A, I. S. (5 February 2009). Alzheimer's disease. from http://dx.doi.org/10.1136/bmj.b158

[3] Orrell, M., \& Sahakian, B. (1995). Education and dementia. BMJ: British Medical Journal, 310(6985), 951.

[4] Stern, C., \& Munn, Z. (2010). Cognitive leisure activities and their role in preventing dementia: a systematic review. International Journal of Evidence-Based Healthcare, 8(1), 2-17.

[5] Lee, B., \& Groves, D. (2014). Seniors Technology, Leisure, and Travel. International Journal of Humanities and Social Science, Vol. 4, No. 14.

[6] Wang, H.-X., Xu, W., \& Pei, J.-J. (2012). Leisure activities, cognition and dementia. Biochimica et Biophysica Acta (BBA)-Molecular Basis of Disease, 1822(3), 482-491.

[7] Verghese, J., Lipton, R. B., Katz, M. J., Hall, C. B., Derby, C. A., Kuslansky, G., Buschke, H. (2003). Leisure activities and the risk of dementia in the elderly. New England Journal of Medicine, 348(25), 2508-2516.
[8] Voice, D. (2004). At home with AT (assistive technology). from http://www.housinglin.org.uk/library/Resources/Housing/Housing_advic e/At_Home_with_AT_-_Dementia_Voice_December_2004.pdf

[9] Riley, P., Alm, N., \& Newell, A. (2009). An interactive tool to promote musical creativity in people with dementia. Computers in Human Behavior, 25(3), 599-608.

[10] Tobiasson, H. (2009). Physical action gaming and fun as a tool within elderly care: Game over or play it again and again. Paper presented at the The 17th Congress of the IEA, Beijing 2009.

[11] Arntzen, A. (2011). Game based learning to enhance cognitive and physical capabilities of elderly people: concepts and requirements. World Acad Sci Eng Tech, 60, 63-67.

[12] Thies, W., \& Bleiler, L. Alzheimer's Association. 2011 Alzheimer's disease facts and figures. Alzheimers Dement 2011; 7: 208-44; PMID: 21414557.

[13] Thompson, O., Barrett, S., Patterson, C., \& Craig, D. (2012). Examining the neurocognitive validity of commercially available, smartphonebased puzzle games. Psychology, 3(07), 525.

[14] Pillai, J. A., Hall, C. B., Dickson, D. W., Buschke, H., Lipton, R. B., \& Verghese, J. (2011). Association of crossword puzzle participation with memory decline in persons who develop dementia. Journal of the International Neuropsychological Society, 17(06), 1006-1013.

[15] Kim, H., Sapre, V., \& Do, E. Y.-L. (2011). Games for health: Design cognition-focused interventions to enhance mental activity $H C I$ International 2011-Posters' Extended Abstracts (pp. 415-419): Springer.

[16] Carrillo, M. C., Dishman, E., \& Plowman, T. (2009). Everyday technologies for Alzheimer's disease care: Research findings, directions, and challenges. Alzheimer's \& Dementia, 5(6), 479-488.

[17] Cowl, A. L., \& Gaugler, J. E. (2014). Efficacy of Creative Arts Therapy in Treatment of Alzheimer's Disease and Dementia: A Systematic Literature Review. Activities, Adaptation \& Aging, 38(4), 281-330.

[18] Gilpin, L. (January 26, 2015). from http://www.techrepublic.com/article/remind-music-app-helpsalzheimers-patients-bring-back-memories/

[19] Speechmark. (30 March 2004). Musical Bingo. from http://www.amazon.co.uk/Musical-Bingo-Speechmark/dp/0863885071

[20] Rosenbaum, E., \& Silver, J. (2010). Singing Fingers: fingerpainting with sound. Paper presented at the Proceedings of the 9th International Conference on Interaction Design and Children.

[21] Zygourisa, S., Giakoumisb, D., Votisb, K., Doumpoulakisb, S., Ntovasa, K., Segkoulic, S., . . . Tsolakia, M. (2014). Can a Virtual Reality Cognitive Training Application Fulfill a Dual Role? Using the Virtual Supermarket Cognitive Training Application as a Screening Tool for Mild Cognitive Impairment. Journal of Alzheimer's Disease, 40, 1-10.

[22] Helander, M. G. (2014). Handbook of human-computer interaction: Elsevier.

[23] Jayroe, T. J., \& Wolfram, D. (2012). Internet searching, tablet technology and older adults. Proceedings of the American Society for Information Science and Technology, 49(1), 1-3.

[24] Dhillon, J. S., Ramos, C., Wünsche, B. C., \& Lutteroth, C. (2011). Designing a web-based telehealth system for elderly people: An interview study in New Zealand. Paper presented at the Computer-Based Medical Systems (CBMS), 2011 24th International Symposium on.

[25] Koster, R. (2013). Theory of fun for game design: " O'Reilly Media, Inc.".

[26] Hallford, N., Hallford, J., \& LaMothe, A. (2001). Swords and Circuitry: A Designer's Guide to Computer Role-Playing Games: Premier Press, Incorporated.

[27] Munson, S. A., \& Consolvo, S. (2012). Exploring goal-setting, rewards, self-monitoring, and sharing to motivate physical activity. Paper presented at the Pervasive Computing Technologies for Healthcare (PervasiveHealth), 2012 6th International Conference on.

[28] Huppert, F. (2003). Designing for older users Inclusive Design (pp. 3049): Springer.

[29] Van Veldhoven, E. R., Vastenburg, M. H., \& Keyson, D. V. (2008). 
Designing an interactive messaging and reminder display for elderly Ambient Intelligence (pp. 126-140): Springer.

[30] Paggetti, C., \& Tamburini, E. (2005). Remote management of integrated home care services: the dghome platform. Paper presented at the Proceedings of the 3rd International Conference on Smart homes and health Telematics, ICOST.

[31] Venkatesh, V., Morris, M. G., Davis, G. B., \& Davis, F. D. (2003). User acceptance of information technology: Toward a unified view. MIS quarterly, 425-478.

[32] Wu, Y.-L., Tao, Y.-H., \& Yang, P.-C. (2007). Using UTAUT to explore the behavior of $3 G$ mobile communication users. Paper presented at the Industrial Engineering and Engineering Management, 2007 IEEE International Conference on.

[33] Moore, G. C., \& Benbasat, I. (1991). Development of an instrument to measure the perceptions of adopting an information technology innovation. Information systems research, 2(3), 192-222.

[34] Hulley, S. B., Cummings, S. R., Browner, W. S., Grady, D. G., \& Newman, T. B. (2013). Designing clinical research: Lippincott Williams \& Wilkins.

[35] Patton, M. Q. (2005). Qualitative research: Wiley Online Library.

[36] Hawthorn, D. (2000). Possible implications of aging for interface designers. Interacting with computers, 12(5), 507-528.

[37] Saini, S., Rambli, D. R. A., Sulaiman, S., Zakaria, M. N., \& Shukri, S. R. M. (2012). A low-cost game framework for a home-based stroke rehabilitation system. Paper presented at the Computer \& Information Science (ICCIS), 2012 International Conference on.

[38] Science, P. L. o. (March 13, 2013). Video game 'exercise' for an hour a day may enhance certain cognitive skills. . Science Daily.
[39] Cohen, A. D., \& Klunk, W. E. (2014). Early detection of Alzheimer's disease using PiB and FDG PET. Neurobiology of disease, 72, 117-122.

[40] Lee, B., Chen, Y., \& Hewitt, L. (2011). Age differences in constraints encountered by seniors in their use of computers and the internet. Computers in Human Behavior, 27(3), 1231-1237.

[41] Zikmund, W., Babin, B., Carr, J., \& Griffin, M. (2012). Business research methods: Cengage Learning.

[42] Zar, J. H. (1999). Biostatistical analysis: Pearson Education India.

[43] Eisma, R., Dickinson, A., Goodman, J., Syme, A., Tiwari, L., \& Newell, A. F. (2004). Early user involvement in the development of information technology-related products for older people. Universal Access in the Information Society, 3(2), 131-140.

[44] Coughlin, J. F. (2010). Understanding the Janus face of technology and ageing: Implications for older consumers, business innovation and society. International Journal of Emerging Technologies and Society, $8(2), 62$.

[45] Muniady, R., Al-Mamun, A., Permarupan, P. Y., \& Zainol, N. R. B. (2014). Factors Influencing Consumer Behavior: A Study among University Students in Malaysia. Asian Social Science, 10(9), p18.

[46] Katona, G. (1974). Psychology and consumer economics. Journal of Consumer Research, 1-8.

[47] Smith, A. W., Moore, A. J., Lamacchia, B. A., Hejlsberg, A., Grunkemeyer, B. M., Doise, C. L., Sinclair, C. T. (2006). Application program interface for network software platform: Google Patents.

[48] Disney. Dodo Pop. from https://play.google.com/store/apps/details?id=com.disney.colorpop_goo 